\title{
Judicial Research on Judgment and Evaluation of Rehabilitation Effect of Drug Rehabilitation
}

\author{
Agueas Darnta \\ Faculty of Law, Universitas Pembangunan Nasional Veteran Jakarta, Indonesia \\ agusdarwantal@gmail.com
}

\begin{abstract}
Narcotics Law No. 35 of 2009 addresses narcotics abuse and illicit narcotic drug trafficking. This law adheres to a doubletrack system in the form of criminal and action sanctions. In court decisions, there can be differences regarding criminal or sanctions actions. This study was subjected to analysis of several rehabilitation decisions for narcotic abuse. Based on assessments from the Integrated Assessment Team, the results of the analysis of the criminal verdicts for rehabilitation in narcotics abuse cases are still diverse and varied. Efforts to fulfil rehabilitation rights for narcotics addicts during the trial process are assessments from the Integrated Assessment Team that state that the accused requires rehabilitation, according to Law No. 35 of 2009. The assessment results should be the basis of the judge's decision in fulfilling rehabilitation rights for narcotics addicts while remaining guided by juridical elements, philosophical elements, and sociological elements.
\end{abstract}

Keywords: assessment, narcotics, criminal, judge's decision, rehabilitation

\section{Introduction}

Narcotics are substances or drugs derived from plants or non-plants, synthetic or semi-synthetic, that can cause a decrease or change in consciousness, loss of taste, pain reduction or elimination, and addiction potential. ${ }^{1}$ Narcotic abuse can result in both physical and mental disorders. This condition is very detrimental when coupled with illicit narcoticstrafficking. Treatment of narcotics addiction necessitates a multi-pronged approach, including psychiatric, medical, legal, and social treatment of addiction. $^{2}$

Victims of narcotics abuse have spread throughout urban and rural areas, regardless of social status, gender, or age, and even among students. ${ }^{3}$ Excessive narcotics abuse is strongly relatedto crime, which can be influenced by several factors such as poverty, personality disorders, social and cultural factors, relationships with other users, and previous incarceration. ${ }^{4}$ Incidents of violence are significantly impacted by narcotics sales and gang membership. ${ }^{5}$

Two factors can be identified as the causes of narcotics crime as a result of narcotics abuse: ${ }^{6}$

\footnotetext{
${ }^{1}$ Sudarsono. ProspekPengembanganObatBahanAlami di Bidang Kesehatan. (Bandung: Citra Aditya Bakti, 2003), hlm. 4.

${ }^{2}$ Nora D Volkow, Ting-Kai Li, "Drugs and Alcohol: Treating and Preventing Abuse, Addiction and Their Medical Consequences", Pharmacology and Therapeutics, 108, 1, (2005), hlm. 3.

${ }^{3}$ TaufikMakarao, Suhasril dan Zakky A.S. TindakPidanaNarkotika (Jakarta: Ghalia Indonesia, 2003), hlm. 17.

${ }^{4}$ Enrique Esbec, Enrique Echeburúa, "Substance Abuse and Crime: Considerations For A Comprehensive Forensic Assessment", Adicciones, 2, 28(1), (2012), hlm. 48.

${ }^{5}$ Matthew D. Phillips, "Assessing the Impact of Drug Use and Drug Selling on Violent Offending in A Panel of Delinquent Youth", Journal Drug Issues. 42, 3, (2012), hlm. 298.

${ }^{6}$ TaufikMakarao, Suhasril dan Zakky A.S, TindakPidanaNarkotika, hlm. 92 .
}

1) Internal factors, factors from narcotics abusers, such as a shaky soul, a sense of hopelessness, discomfort, and anxiety.

2) External factors, factors originating from outside narcotics abusers, such as associations, environmental influences, and pressure from specific parties.

According to data from the National Narcotics Board of the Republic of Indonesia (BNN), there were 4.364 addicts and/or victims of narcotics abusers who received rehabilitation services, both inpatient and outpatient, at Balai/Loka and BNN clinics in Province/BNN Regency throughout Indonesia in $2020 .{ }^{7} \mathrm{BNN}$ believes that providing medical and social rehabilitation to prisoners, will be able to reduce the number of narcotics abusers. ${ }^{8}$

Narcotics addicts are SelfVictimizing Victims,meaning that their suffering is caused by their narcotics abuse.Rehabilitation is thought to be capable of relieving narcotic dependence until they canenjoy a normal life without narcotics. ${ }^{9}$

Narcotics abuse and illicit traffic in narcotic narcotics are classified as criminal acts under Narcotics Law Number 35 of 2009, which follows a "double track system", namely action sanctions and criminal sanctions. ${ }^{10}$ The application of

${ }^{7} \mathrm{Https} / / /$ bnn.go.id/press-release-akhir-tahun-2020/, Humas BNN Sikap BNN Tegas, Wujudkan Indonesia Bebas Dari Narkotika". Diakses 28/3/2021.

${ }^{8} \mathrm{Https} / / /$ bnn.go.id/resolusi-pemasyarakatan-kemenkumham-tahun2020-21-540-narapidana/Humas BNN ResolusiPemasyarakatanKemenkumhamTahun 2020: 21.540 NarapidanaPenggunaNarkobaDirehabilitasi, Diakses 28/3/2021.

${ }^{9}$ Lydia HarinaMartono dan Satya Joewana. Peran OrangtuadalamMencegah dan MenanggulangiPenyalahgunaanNarkotika. (Jakarta: Balai Pustaka 2006), hlm. 87.

${ }^{10}$ Dani Krinawati dan Niken S.B. Utami "PelaksanaanRehabilitasiBagiPecanduNarkotikaPascaBrelakunyaP eraturanBresama 7 (Tujuh) Lembaga Negara Republik Indonesia", JurnalMimbar Hukum, 27, 2, (2015), hlm. 227. 
action sanctions in the form of medical and social rehabilitation is ruled by Article 54, which states that narcotics addicts are obliged to undergo rehabilitation. According to Article 103, judges can decide that narcotics addicts are subject to action sanctions in the form of rehabilitation, and Article 127 paragraph (3) mandates that if the person is proven to be a victim of narcotics abuse, rehabilitation is mandatory to be carried out. ${ }^{11}$

Medical rehabilitation and social rehabilitation are the two types of rehabilitation. According to Article 56 of the Narcotics Law, "Medical rehabilitation of narcotic addicts is carried out in hospitals appointed by the Minister or certain rehabilitation institutions organised by government agencies or the public may carry out medical rehabilitation of narcotic addicts after receiving approval from the Minister."

According to Article 59 of the Narcotics Law, "the implementation of the provisions referred to in Articles 56 and 57 is regulated by a Ministerial Regulation, and the implementation of the provisions referred to in Article 58 is regulated by a Ministerial Regulation that administers government affairs in the social sector is regulated by a Ministerial Regulation."

The imposition of sanctions for social and medical rehabilitation is also regulated in several provisions, including:

1) Supreme Court Circular (SEMA) No. 4 of 2010 concerning Placement of Abusers, Victims of Narcotics Abuse into Medical and Social Institutions;

2) Government Regulation no. 25 of 2011 concerning the Implementation of Compulsory Reporting Narcotics Addicts to obtain therapy and rehabilitation services;

3) Decree of the Minister of Health No. HK 02.02/MENKES/502/2015 which appoints 434 recipient agencies that are required to report (IPWL) in 33 provinces:

4) Joint Regulation of the Chief Justice of the Republic of Indonesia, the Minister of Law and Human Rights of the Republic of Indonesia, the Minister of Social Affairs of the Republic of Indonesia, the Attorney General of the Republic of Indonesia, KAPOLRI and the Head of the Indonesian National Narcotics Agency No. 01/PB/MA/III/2014, No. 03 of 2014, No. 11 of 2014, No. PER-005/A/JA/03/2014, No. 1 of 2014, No. PERBER/01/III/2014/BNN concerning Handling of Narcotics Addicts and Victims of Narcotics Abuse in Rehabilitation Institutions.

The Joint Regulations serve as guidelines at the investigation, prosecution, and trial levels, ensuring that the medical and social rehabilitation processes are synergistic and integrated. This is followed by the formation of an Integrated Assessment Team at the central, provincial, and district/city levels. The Integrated Assessment Team is a group of doctors and legal professionals tasked with conducting legal, medical, and psychosocial analyses before developing a rehabilitation plan that includes the length of

${ }^{11}$ Sumarno Masum. PenanggulanganBahayaNarkotika dan KetergantunganObat. (Jakarta: Haji Masagung, 2007), hlm. 138. time required for rehabilitation. The assessment results are used as the completeness of the case file, namely as a written statement made based on the investigator's request containing everything seen and found in the examination in accordance with his knowledge as well as possible for the benefit of the judiciary by remembering the oath when accepting the position.

SEMA No. 4 of 2010 has explained the limitations of certain types of narcotics abuse and things that judges can consider when deciding whether or not narcotics abuse defendants should receive rehabilitation measures. Following rehabilitation, narcotics abusers are expected to be properly accepted back into the community and not repeat their actions. $^{12}$

One of the most important aspects in determining the value of the judge's decision is the judge's considerations, which include justice (ex aequo et bono), legal certainty, and benefits for interested parties. ${ }^{13}$ The panel of judges considers the procedure for submitting a request for narcotics rehabilitation very strictly or selectively when deciding on whether or not to rehabilitate narcotics addicts. The rules that are considered include Article 3 paragraph (1) Regulation of the Head of the National Narcotics Agency no. 11 of 2014 concerning "Procedures for Handling Narcotics Addicts and/or Defendants of Narcotics Addicts and Narcotics Victims into Rehabilitation Institutions, which states that narcotics addicts and victims of narcotics abuse without rights and are breaking the law as suspects and/or defendants in narcotics abuse who are undergoing the process of investigation, prosecution and trial in court is given treatment, care and recovery in a rehabilitation institution.”

The Public Prosecutor may request assistance from the local Integrated Assessment Team to conduct an assessment of the accused for the benefit of the prosecutor and the Judge for examination in court. The judge's decision, which will determine whether the person concerned, in this case, a narcotics addict, is undergoing rehabilitation or not, is based on whether the narcotic crime has been committed. This means that a person is examined in court before a judge's decision determines whether or not they are rehabilitated. ${ }^{14}$

${ }^{12}$ Diyono and Amin Purnawan, "Judges Existencing in The Judicial Process of Narcotics Criminal Actors", Law Development Journal, 2, 3, (2020), hlm. 323.

${ }^{13}$ Erik Harun Alrosid. "Legal Considerations Of The Judges In Narcotics Rehabilitation Decisions (Analysis of Decisions Number: 112 / Pid.Sus / 2018 / Pn.Pwt.)", UMPURWOKERTO LAW REVIEW, 1, 2, (2020), hlm. 61.

${ }^{14}$ Tri Jata Ayu Pramesti. "Tata Cara PengajuanPermohonanRehabilitasi

Narkotika",https://www.hukumonline.com/klinik/detail/ulasan/lt 560211ea73636/tata-cara-pengajuan-permohonan-rehabilitasinarkotika, Diakses 28/3/2021.

${ }^{15}$ Dirdjosisworo,S.,SegiHukumtentangNarkotikadiIndonesia (Bandung:KaryaNusantara, 2000), hlm.14.

${ }^{16}$ TaufikMakarao, Suhasril dan Zakky A.S TindakPidanaNarkotika, hlm.74 
Based on this description, in this study, we have researched the application of assessments to rehabilitation decisions for narcotic abuse.

\section{Problem Formulation}

How is the juridical study of the application of assessment on rehabilitation decisions for narcotics abuse carried out?

\section{Research Method}

The normative legal research method was used, with a statutory approach, a conceptual approach, and a case approach. The case approach is used to analyse and evaluate the use of narcotics addict assessment in rehabilitation decisions related to narcotics crimes.

The researcher studied and grouped the data based on the related issues, and then analysed the results of organising the data using the rules, theories, and arguments relating to the application of the assessment to the rehabilitation decision for the crime of narcotics abuse in accordance with the applicable laws and regulations, as well as other related legal documents and journals.

\section{Results and Discussion}

\subsection{The Basic for Judge's Consideration in Sentencing against Narcotics Abuse}

Judges must play a role in preventing and reducing narcotic abuse crimes. According to the principle of justice, the judge's decision must take into account all relevant factors. A judge's authority comes from his or her ability to determine the type and level of punishment. One of the freedoms that a judge should have is the authority to determine the minimum and maximum limits of criminal sanctions that have been regulated by law for each criminal act. As a result, the judge has complete control over criminal case decisions. ${ }^{15}$

Judges must understand the implications of punishment for those who commit criminal acts involving narcotics abuse. Furthermore, judges must be aware of the goals that will be achieved by imposing a sentence on narcotics abusers. As a result, during the decision-making process, a judge must be guided by a set of criminal policies that will influence the next stage. A judge's decision is usually complicated. It is a consideration that a judge must give to the convict by paying attention to the principles of imposing a crime from a written juridical point of view as well as unwritten principles. A judge should be able to consider the nature and seriousness of the offence committed, as well as the circumstances surrounding the acts brought before him. Other parties, particularly convicts, should be able to follow the thought process that leads to the decision to charge someone with a crime. This consideration must be taken into account by the judge when making a decision. However, the reality demonstrates that there are still differences in the periods involved in the verdicts of narcotics abuse cases.

\subsection{The Basic Laws in Imposing Rehabilitation Sentences against Narcotics Abuse}

The decision of the judge must be based on sound reasoning and the principle of justice. Judges have the authority to determine the nature of the crime as well as the duration of the punishment. The ability of judges to set the minimum and maximum levels of criminal sanctions is one of their many powers and liberties.

Judges must comprehend the intent and purpose of the sentencing. The decision of the judge must be consistent with the policy for dealing with the next stage of the crime. It must be understood that the decisions made by the judges are complicated. The sentence imposed by the judge on the convict must have a basis for consideration, which must include, among other things, the principles of imposing a crime from a written juridical standpoint as well as unwritten principles. Other people, particularly the convict, must follow the thought process of imposing a sentence. In fact, it was discovered that there were differences in the length of time between the verdicts in cases of narcotics abuse.

According to the general provisions chapter of Article 1 number 15 of Law No. 35 of 2009, "narcotics abusers are people who use narcotics without rights or against the law." Even if someone uses narcotics, they still have human rights because these rights are inherent in their nature and dignity as human beings. This means that the state has an obligation to provide legal protection for narcotics users, including fulfilling their rights as victims, particularly the right to guidance and rehabilitation. Dirdjosisworo stated that " narcotics abuse victims require therapy."

There are several articles on guidance and supervision in Law No. 35 of 2009, specifically in Chapter IX, and more explicitly in Article 54, which states: "Narcotics addicts and victims of narcotics abuse are obliged to undergo medical rehabilitation and social rehabilitation."

The judge's decision whether rehabilitation or imprisonment for narcotics abusers is limited by the following regulations:

1. UU no. 35 of 2009 concerning Narcotics

Article 16 of Law No. 35 of 2009 states: "Medical Rehabilitation is a process of integrated treatment activities to free addicts from narcotic dependence." Article 17 of Law No. 35 of 2009 states: "Social Rehabilitation is a process of integrated recovery activities, both physically, mentally, and socially, so that former narcotics addicts can return to carrying out their social functions in people's lives." This is covered in a special chapter on the implementation of rehabilitation, which includes Article 53, Article 54, Article 55, Article 56, Article 57, Article 58, Article 59, and Article 103.

2. The Joint Regulation of the Chairman of the Supreme Court of the Republic of Indonesia, the Minister of Law and Human Rights of the Republic of Indonesia, the Minister of Health of the Republic of Indonesia, the Minister of Social Affairs of the Republic of Indonesia, 
the Attorney General of the Republic of Indonesia, KAPOLRI, the Head of the National Narcotics Board of the Republic of Indonesia, regarding the Handling of Narcotics Addicts and Victims of Narcotics Abuse in Rehabilitation Institutions.

Technical matters that are not regulated in Narcotics Law No. 35 of 2009 on the implementation of rehabilitation are regulated in this joint decision contained in Chapter III regarding the implementation of articles 3 to 6 .

Article 3 states that addicts, abusers, and victims of abuse have the right to apply for an integrated assessment to obtain rehabilitation after becoming suspects. The implementation of rehabilitation is also proposed by addicts, abusers, and victims of narcotics abusers who, when arrested, have no evidence but laboratory results show that they use narcotics, of course, based on the implementation of the results of an integrated assessment. This does not apply to addicts or narcotics abusers whose evidence exceeds the limit in accordance with the applicable rules, as stated in Article 4 of this provision.

\section{SEMA No. 4 of 2010}

Provision number 2 in this SEMA explains that the application of a criminal, as referred to in Law number 35 of 2009, article 103 letters a and b, can only be imposed with a criminal classification: a. The defendant was arrested by POLRI (Indonesian Police) investigators and BNN investigators in the condition of being caught redhanded. b. At the time of being caught red-handed, evidence of 1 (one) day of use was found, with a certain number of details". For evidence that is still within the usage limit of one day or less, the judge in the case of imposing a sentence in the form of legal action for rehabilitation.

\subsection{The Application of Assessment in Rehabilitation Decisions}

In this study, two court decisions imposing rehabilitation crimes on victims of narcotics abuse were compared: Semarang District Court Decision No. 407/Pid.SUS/2016/PN.Smg and Surakarta District Court Decision No. 31/Pid.Sus/2016/PN.Skt.

According to the Semarang District Court Decision No. 407/Pid.SUS/2016/PN.Smg, the defendant was sentenced to social rehabilitation for 6 (six) months. The assessment considerations used are "Recommendations on the Implementation of Assessment Results in the Central Java BNNP legal process No: R/185/IV/Ka/TAT.00/2016/ BNNPJTG dated April 14, 2016, signed by dr.Raditya was known by the Head of BNN Central Java Province, Drs.AmrinRemico, MM concluded that the defendant was a victim of narcotics abuse and had to undergo social rehabilitation for 3 (three) months. That the defendant is currently undergoing social rehabilitation for three (three) months at the Baresos for former drug abusers "Mandiri" Semarang from 2 May 2016 to 2 August 2016 in accordance with the assessment results." One tube of used urine was submitted as evidence.
On the other hand, according to the Surakarta District Court Decision No. 31/Pid.Sus/2016/PN.Skt, the defendant was sentenced to 6 (six) months of imprisonment and rehabilitation at Pusat RehabilitasiRumahSakit Jiwa (RSJ) Surakarta. The assessment considerations are as follows: Expert witness testimony by dr. Wahyu Nur Ambarwati, Sp.K.J, M.Kes against the Defendant. Apart from being sentenced to a crime, they also need to be ordered to undergo treatment and treatment through medical and social rehabilitation. The results of the defendant's assessment were shown in the trial. The defendant included a severe dependence, so the best step that must be taken is treatment by means of rehabilitation, where the defendant can be rehabilitated at the Surakarta Mental Hospital. That the standard for rehabilitation is 3-6 months of hospitalisation at a designated hospital. Existing evidence includes: - 2 (two) packages of methamphetamine type narcotics weighing $0.262 \mathrm{~g}$ and $0.252 \mathrm{~g},-1$ (one) glass pipette containing 0.004 $\mathrm{g}$ of methamphetamine type narcotic residue, a set of shabu (bong), and - 1 (one) unit of mobile cellular.

The following are the basic considerations for the criminal rehabilitation of Narcotic abusers in general, based on the examples of court decisions that have been submitted:

According to the Panel of Judges, the defendant deserves to be placed in a social/medical rehabilitation centre appointed by the government or the Ministry of Health in order to receive intensive and continuous treatment as recommended by the Circular Letter of the Supreme Court Number 4 of 2010 concerning the Placement of Victims of Abuse and Narcotics Addicts into Medical Rehabilitation and Social Rehabilitation Institutions.

Based on the explanation above, SEMA is a form of circular from the Supreme Court in the form of an appeal from the Supreme Court to all levels of the judiciary whose contents are technical instructions in the administration of justice, which is more administrative in nature. Detaining inmates and prisoners involved in drug cases is not a good act because it ignores the interests of care and treatment. This is based on the consideration that most of the prisoners and detainees in drug cases are categorised as users or even victims, which, if viewed from the health aspect, means they are actually people who are sick. However, at this time, this cannot be supported from the perspective of the condition of the correctional institution. This is considered to have a negative impact on other criminal behaviour that can further worsen mental conditions, and the health suffered by narcotic convicts will be even more severe.

The basis for consideration of the Panel of Judges in Imposing a Rehabilitation Decision by taking into account articles 54, 103, 127 paragraph (1) letter of the Republic of Indonesia Law No. 35 of 2009 concerning Narcotic, and SEMA No. 4 of 2010. This decision is commendable and should be considered by all other judges because, in this case, the Panel of Judges views Narcotic abusers as sick people who require medical treatment. Prison is not the appropriate environment for them. This is still consistent with Van Hammel's definition of criminal law, which is the overall basis and rules adopted by the state in its obligation to enforce the law, namely by prohibiting what is contrary to 
the law (on recht) and imposing suffering on those who violate the prohibition.

Current developments indicate a strong tendency to change in how narcotic abusers are viewed. They are no longer viewed as criminals, but as victims or patients who require empathy. Narcotics abusers who are found guilty by a judge of the narcotic crime they have committed may decide to order the person concerned to undergo treatment and/or treatment in order to provide an opportunity for the person concerned to be free from their addiction. Likewise, if the narcotics abuser is not proven guilty on charges of committing a narcotic crime, the judge may decide to order the person concerned to undergo treatment and/or treatment.

According to the findings of Yusuf Saefuddin, a case study at Purbalingga District Court, an integrated assessment is a mechanism designed to distinguish drug abusers and addicts from drug dealers and to develop treatment plans for drug addicts and abusers. However, in practice, several obstacles were discovered, including the late release of assessment requests and assessment results, a lack of coordination between the Integrated Assessment Team, insufficient facilities for the Integrated Assessment Team secretary, limited facilities for rehabilitation facilities, and the rehabilitation programme did not run procedurally. ${ }^{16}$

According to the findings of Ibn Sakdan, the judge did not order rehabilitation because the expert was not present at the trial to explain why narcotics addicts needed to be rehabilitated, the perpetrators denied being narcotics addicts, and the public prosecutor never requested that the defendant be rehabilitated. The National Narcotics Board of the Republic of Indonesia (BNN) implemented the rehabilitation programme in 2015 and 2016, but it was suspended the following year due to a lack of funds. The rehabilitation provided includes medical and social rehabilitation, integrated treatment for the healing of narcotics addicts, as well as mental and social recovery so that former addicts are ready to return to society. ${ }^{17}$

According to the research findings ofEnrique, ${ }^{18}$ there is a strong link between drug use and crime, but this relationship is complicated. Even among casual users or addicts, drug use does not always result in an increase in criminal activity such as theft, rape, or assault. The majority of addicts are responsible for the majority of criminal behaviour motivated by addiction, but addiction can, in some cases, impair a person's ability to control his or her actions. The Spanish Criminal Justice System is currently investigating various aspects of drug abuse, with a focus on court decisions concerning the nature and enforcement of drug laws. It also discusses criminal responsibility for drug abuse and drugrelated crimes, as well as drug laws, alternative penalties for drug offences, and drug treatment options. In this field, expert evidence is crucial in court for rehabilitation.

${ }^{22}$ Enrique Esbec, Enrique Echeburúa, "Substance Abuse and Crime: Considerations for A Comprehensive Forensic Assessment", Adicciones, 2, 28, (2016), hlm.48.
According to the findings of the Virginia case study, the effectiveness of narcotics rehabilitation programmes for offenders must be monitored with instruments that can reliably assess the risks and needs of offenders, guide the treatment planning process, track progress over time, and provide services within a large and intensive therapeutic community programme. ${ }^{19}$

\section{Conclusion}

According to the descriptions provided concerning the Semarang District Court Decision No. 407/Pid.SUS/2016/PN. Smg and the Surakarta District Court Decision No. 31/Pid.Sus/2016/PN.Skt., it can be concluded that: the District Court judges' consideration in imposing a prison sentence, a fine with rehabilitation is in accordance with the applicable provisions based on Article 103 paragraph (1) and Article 103 paragraph (2) of Law No. 35 of 2009 concerning Narcotics. As an additional crime, the judge has the authority to impose a criminal decision in the form of rehabilitation onnarcotics users. Medical rehabilitation and non-medical (social) rehabilitation are both possible. Because it is a healing effort carried out through health science, the benefits of medical rehabilitation are extremely important. Nonmedical social rehabilitation seeks to reintegrate narcotics addicts into society so that they can be accepted and socialised easily.

\section{Suggestion}

The advice given is that the judge who examines the narcotics crime should impose a rehabilitation sentence in his decision, either with or without the crime of deprivation of liberty. The rights of addicts to get rehabilitation are regulated by Law No. 35 of 2009 concerning Narcotics, specifically Article 54. According to the article, narcotics addicts and victims of narcotics abuse must receive medical and non-medical rehabilitation.

\section{References}

\section{Books}

[1] Dirdjosisworo, S., Segi Hukumtentang NarkotikadiIndonesia. Bandung: Karya Nusantara, 2000.

[2] Henry Pandapotan Panggabean. Fungsi Mahkamah AgungBersifatPengaturan. Yogyakarta: Liberty, 2005.

[3] KementerianKesehatanRI,GambaranUmumPenyalahg unaanNarkoba,JendelaData DanInformasiKesehatan, Semester I,2014.

[4] Lydia HarinaMartono, Satya Joewana. Peran OrangtuadalamMencegah dan MenanggulangiPenyalahgunaanNarkotika. Jakarta: Balai Pustaka, 2006.

[5] SatjiptoRaharjo,HukumdanMasyarakat. Bandung: Angkasa, 1980.

${ }^{23}$ Edward A. Roberts, Michael W. Contois, James C. Willis, Mary Rose Worthington and Kevin, "Assessing Offender Needs and Performance for Planning and Monitoring Criminal Justice Drug Treatment", Criminal Justice andBehavior, 34, 1179, (2007), hlm.1179. 
[6] Sudarsono. ProspekPengembanganObatBahanAlami di Bidang Kesehatan. Bandung: Citra Aditya Bakti, 2003.

[7] Sumarno Masum. PenanggulanganBahayaNarkotika dan KetergantunganObat. Jakarta: Haji Masagung, 2007.

[8] TaufikMakarao, Suhasril dan Zakky A.S. TindakPidanaNarkotika. Jakarta: Ghalia Indonesia, 2003.

\section{Journals}

[1] Dani Krinawati dan Niken S.B. Utami. "PelaksanaanRehabilitasiBagiPecanduNarkotikaPasca BerlakunyaPeraturanBresama 7 (Tujuh) Lembaga Negara Republik Indonesia", JurnalMimbar Hukum, 27, 2, (2015): 226-240. DOI: https://doi.org/10.22146/jmh.15894.

[2] Diyono and Amin Purnawan, "Judges Existencing in The Judicial Process of Narcotics Criminal Actors", Law Development Journal, 2, 3, (2020): 323-330. DOI: http://dx.doi.org/10.30659/ldj.2.3.\%25p.

[3] Edward A. Roberts, Michael W. Contois, James C. Willis, Mary Rose Worthington and Kevin, "Assessing Offender Needs and Performance for Planning and Monitoring Criminal Justice Drug Treatment", Criminal Justice and Behavior, 34, 9, (2007): 11791187.

DOI: https://doi.org/10.1177\%2F0093854807304350.

[4] Enrique Esbec, Enrique Echeburúa, "Substance Abuse and Crime: Considerations for A Comprehensive Forensic Assessment”, Adicciones, 2, 28, (2016): 4856. DOI: http://dx.doi.org/10.20882/adicciones.790.

[5] Erik Harun Alrosid. "Legal Considerations of The Judges in Narcotics Rehabilitation Decisions (Analysis of Decisions Number: 112/Pid.Sus/2018/Pn.Pwt.)", , 1, 2, (2020): 61-72. DOI: HTTP://DX.DOI.ORG/10.30595/UMPLR.V1I2.8664.

[6] IbnuSakdan, Dahlan Ali, Mahfud, "The Implementation of Medical and Social Rehabilitation for Addicts and Narcotics Abuse," Petita, 4, 2, (2019): 180-194. DOI: https://doi.org/10.22373.

[7] Matthew D. Phillips, "Assessing the Impact of Drug Use and Drug Selling on Violent Offending in A Panel of Delinquent Youth", Journal Drug Issues, 42, 3, (2012): 298-316. DOI: https://doi.org/10.1177\%2F0022042612456017.

[8] Nora D Volkow, Ting-Kai Li, "Drugs and Alcohol: Treating and Preventing Abuse, Addiction and Their Medical Consequences", Pharmacology and Therapeutics, 108, 1, (2005): 3-17. DOI: http://dx.doi.org/10.1016/j.pharmthera.2005.06.021.

[9] Yusuf Saefudin, Agus Raharjo, Budiono Budiono, "Urgency of Integrated Assessment on Drugs Crime (A Study in Purbalingga Regency)", JurnalDinamika Hukum, 17, 1, (2017): 40-52. DOI: http://dx.doi.org/10.20884/1.jdh.2017.17.1.818.

\section{Legislation}

[1] Republic of Indonesia, the 1945 Constitution of the Republic of Indonesia.

[2] Republic of Indonesia, Law Number 35 of 2009 concerning Narcotics.
[3] Republic of Indonesia, Government Regulation Number 25 of 2011 concerning the Implementation of Compulsory Reporting of Narcotics Addicts.

[4] Republic of Indonesia, Joint Regulation of the Chief Justice of the Republic of Indonesia, the Minister of Law and Human Rights of the Republic of Indonesia, the Minister of Social Affairs of the Republic of Indonesia, the Attorney General of the Republic of Indonesia, the Head of the Indonesian Police and the Head of the National Narcotics Agency of the Republic of Indonesia Number: 01/PB/MA/III/2014, Number: 03 of 2014, Number 11 of 2014, Number 03 of 2014, Number: PER-005/A/JA/03/2014, Number: 1 of 2014, Number PERBER/01/III/2014/BNN concerning Handling of Narcotics Addicts and Victims of Abuse Narcotics into the Rehabilitation Institute.

[5] Republic of Indonesia, Regulation of the Head of the National Narcotics Agency Number 11 of 2014 concerning Procedures for Handling Suspects and/or Defendants of Narcotics Addicts and Narcotics Victims in Rehabilitation Institutions.

[6] Republic of Indonesia, Circular Letter of the Supreme Court Number 4 of 2010 concerning Placement of Abusers, Victims of Narcotics Abuse into Medical and Social Institutions.

[7] Republic of Indonesia, Semarang District Court. Decision Number 407/Pid.SUS/2016/PN.Smg

[8] Republic of Indonesia, Surakarta District Court. Decision Number 31/Pid.Sus/2016/PN.Skt

[9] Republic of Indonesia, Tapaktuan District Court. Decision Number 7/Pid.Sus/2017/PN Tn

[10] Republic of Indonesia, Tangerang District Court. Decision Number 1025/Pid.Sus/2019/PN.Tng

[11] Republic of Indonesia, Makassar District Court. Decision Number 1793/Pid.Sus/2020/PN.Mks 